\title{
PENINGKATAN PENCAPAIAN KOMPETENSI SISWA KELAS VIII G SMP NEGERI 2 PARON PADA MATERI SISTEM PENCERNAAN MANUSIA DENGAN PENDEKATAN SAINTIFIK MELALUI MEDIA PUZZLE
}

\author{
Tri Lukitaningsih \\ SMP Negeri 2 Paron, Ngawi \\ Email: trilukita@gmail.com
}

Diterima 22 Januari 2015 disetujui 12 Februari 2015

\begin{abstract}
The purpose of this action research is to improve the competence learning material digestive system in class VIII G of SMP Negeri 2 Paron with scientific learning through the medium of the puzzle. Research carried out for 3 months starting in September 2014 to November 2014. The subject of this class action research was a number of 29 students. Data collection was performed by the method of observation and testing methods. Observation is aimed at three competencies: (1) the competence of attitude, (2) the competence of knowledge, (3) skills competency. The results showed that students' learning competence has increased, ie if the initial reflection completeness reached $59 \%$ in the first cycle increased to $69 \%$ and in the second cycle increased to $86 \%$. Figures incompleteess decreased if the initial reflection of $41 \%$ then the first cycle decreased to $31 \%$ and the second cycle decreased to $14 \%$. On average class increased if the initial reflection at 69 then the first cycle increased to 71 and the second cycle increased to 75 . Thus, with these results it can be said that the puzzle able to enhanced student competence
\end{abstract}

Keywords: Puzzle, scientific, learning competence

\section{PENDAHULUAN}

Kurikulum 2013 menerapkan pendekatan saintifik dalam pembelajaran dan penilaian otentik yang menggunakan prinsip penilaian bagian dari pembelajaran. Untuk memperkuat pendekatan ilmiah (scientific), perlu diterapkan pembelajaran berbasis penyingkapan/penelitian (discovery/ inquiry learning). Untuk mendorong kemampuan peserta didik agar menghasilkan karya kontekstual, baik individual maupun kelompok maka sangat disarankan menggunakan pendekatan pembelajaran yang menghasilkan karya berbasis pemecahan masalah (problem based learning) dan pembelajaran berbasis projek (project based learning) (Kemdiknas, 2013).

Pendekatan saintifik atau pendekatan ilmiah merupakan pendekatan pembelajaran yang bercirikan dimensi pengamatan, penalaran, penemuan, pengabsahan, dan penjelasan tentang suatu kebenaran. (Kemendiknas, 2013). Pendekatan ini diharapkan pada proses pembelajaran peserta didik secara aktif mengkontruksi pengetahuan, ketrampilan dan sikap melalui tahapan mengamati, menanya, menalar, mencoba, dan membentuk jejaring untuk semua mata pelajaran.

Pembelajaran IPA dengan pendekatan santifik dapat diterapkan melalui keterampilan proses sains. Keterampilan proses sains merupaka seperangkat keterampilan yang digunakan para ilmuwan dalam melakukan penyelidikan ilmiah. Keterampilan proses perlu dikembangkan melalui pengalaman-pengalaman langsung sebgai pengalaman pembelajaran. Dengan pengalaman langsung diharapkan peserta didik dapat lebih menghayati proses atau kegiatan yang sedang dilakukan.

Pembelajaran secara umum sedikit banyak dipengaruhi oleh adanya perkembangan dan penemuan-penemuan dalam bidang keterampilan, ilmu, dan teknologi. Pengaruh perkembangan tersebut tampak jelas dalam upaya-upaya pembaharuan sistem sistem pendidikan dan pembelajaran. Salah satu bagian yang 
integral itu dari uapaya pembaharan itu adalah pengimplementasian Kurikulum 2013 yang menekankan pada pendekatan ilmiah atau scientific approach pada proses pembelajaran.

Upaya pembaharuan sistem pendidikan dan pembelajaran moderen bukan hanya menyentuh pada sarana fisik atau fasilitas pendidikan, tetapi pada proses pembalajaran harus menyenangkan. Paradigma baru pembelajaran di sekolah perlu dikedepankan untuk menciptakan suasana pembelajaran yang menyenangkan. Untuk menciptakan pembelajaran menyenangkan seorang guru harus memiliki pengetahuan, kemampuan dan keterampilan memanfaatkan fasilitas yang tersedia, cara kerja yang inovatif, serta sikap positif terhadap tugas-tugas kependidikan yang diembannya. Salah satu bagian yang penting dalam mengupayakan pembelajaran yang menyenangkan adaah penggunaan media pembelajaran. Media pembelajaran menjadi suatu bidang yang seyogyanya dikuasai oleh seorang pendidik yang profesional. Selain itu penggunaan metode pembalajaran atau model-model pembelajaran belum secara maksimal akan menyebabkan pembelajaran yang monoton atau membosankan bagi peserta didik, sehingga peningkatan kompetensi peserta didik tidak akan tercapai.

Pembelajaran diarahkan untuk mendorong peserta didik mencari tahu dari berbagai sumber observasi, mampu merumuskan masalah (menanya) bukan hanya menyelesaikan masalah. Di samping itu pembelajaran diarahkan untuk melatih peserta didik berpikir analitis (pengambilan keputusan) bukan berpikir mekanistis (rutin) serta mampu kerjasama dan kolaborasi dalam menyelesaikan masalah.

Penerapan Kurikulum 2013 di SMP Negeri 2 Paron diawali tahun pelajaran 2013/2014 dan dilanjutkan pada tahun pelajaran 2014/2015, karena SMP Negeri 2 Paron merupakan salah satu sekolah piloting proyek. Pelaksanaan Kurikulum 2013 di sekolah ini masih banyak kendala. Stekholder perlu banyak belajar demi peningkatan pemahaman Kurikulum 2013 ini. Khusunya pada mata pelajaran IPA Terpadu terdapat beberapa perubahan, diantaranya adalah konsep pembelajaran terpadu IPA (integrative science). Konsep keterpaduan ini ditunjukkan dalam Kompetensi Inti (KI) dan Kompetensi Dasar (KD) yakni dalam satu KD sudah memadukan konsep-konsep IPA dari bidang Biologi, Fisika, Kimia, dan Ilmu Pengetahuan Bumi dan Antariksa (IPBA). Perubahan ini tentu saja berdampak pada proses pembelajaran IPA. Dampak yang lebh menonjol adalah ketercapaian kompetensi peserta didik di setiap kompetensi dasar akan berbeda, karena setiap KD memiliki karakteristik berbeda pula.

Hasil analisis ulangan harian setiap kompetensi dasar pada semester ganjil belum menghasilkan ketercapaian yang maksimal atau rata-rata masih dibawah KKM yang ditetapkakan yaitu 70. Adapun yang paling rendah dari hasil analisis tersebut adalah pada kompetensi dasar sistem pencernaan manusia, ketuntasan nilai hasil ulangan harian hanya 59\%, dengan nilai rata-rata 69 untuk itu perlunya solusi untuk peningkatan pemahaman materi tersebut.

Berdasarkan fakta-fakta tersebut di atas maka penulis meneliti peningkatan ketercapaian kompetensi peserta didik dalam proses pembelajaran IPA menggunakan pendekatan saintifik yang dipadukan dengan media puzzle ini dapat merubah proses pembelajaran menjadi lebih menyenangkan dan hasil ketercapaian kompetensi peserta didik semakin meningkat.

\section{METODE}

Penelitian ini menggunakan rancangan penelitian tindakan kelas (PTK). Rancangan PTK dipilih karena beberapa alasan, pertama, penelitian pembelajaran yang berkonteks kelas ini dilaksanakan oleh guru untuk memecahkan masalah-masalah yang terdapat dalam proses pembelajaran termasuk pembelajaran IPA materi sistem pencernaan makanan. Kedua, penelitian ini dilaksanakan untuk memperbaiki 
pembelajaran IPA dan meningkatkan hasil belajar dengan alternatif pengelolaan kelas yang lebih konduktif dalam pembelajaran IPA dan lebih menyenangkan. Ketiga, bentuk kajian yang dilakukan di kelas bersifat refleksif oleh guru untuk meningkatkan kemampuan rasional dalam melaksanakan tugas memperbaiki praktik pembelajaran dilakukan dalam konteks alamiah yaitu untuk mengkaji permasalahan faktual dalam pembelajaran keterampilan IPA sistem pencernaan makanan manusia. Keempat, penelitian ini dilaksanakan secara kolaborasi dengan guru IPA kelas VIII dalam menyusun perencanaan, pelaksanaan dan pengambilan kesimpulan terhadap proses pembelajaran IPA sistem pencernaan makanan manusia, serta dilaksanakan secara berkelanjutan. Keseluruhan tahapan dilakukan secara simultan dari awal hingga akhir. Penelitian ini memiliki siklus yang bersifat spriral mulai dari perencanaan, melakukan tindakan, dan pengamatan faktual, sampai dengan refleksi proses dan hasil tindakan. Penelitian ini dirancang selama 2 siklus.

Subjek penelitian ini adalah siswa kelas VIII G SMP Negeri 2 Paron yang berjumlah 29 peserta didik. Seluruh siswa dikenai tindakan, hal ini dilakukan karena penelitian tindakan kelas merupakan penelitianyangmengikutialurpembelajaran yang sesungguhnya. Penelitian tindakan ini bersifat longitudinal, penelitiannya berlangsung mulai dari pengamatan awal, perencanaan tindakan, pelaksanaan tindakan, observasi, dan refleksi.

Analilsis data dilakukan berdasarkan tahapan analisa model mengalir yang dikemukakan Miles dan Huberman (1992). Kegiatan analisis tersebut ada tiga tahapan yakni (1) tahap reduksi data, (b) tahap penyajian data, dan (3) tahap penarikan kesimpulan. Analisis data dapat dilakukan selama dan sesudah penelitian dengan bertumpu pada proses dan hasil belajar siswa.

Reduksi data dilakukan pada saat dan sesudah kegiatan pengumpulan data berupa aktivitas, latar, dan situasi pembelajaran, berlangsung. Penyajian data dilakukan dengan memaparkan semua data yang telah direduksi. Data pene $\neg$ litian sudah diorganisasikan dan diklasifikasikan pada masing-masing tahapan. Penarikan kesimpulan dilakukan setelah tahapan analisis berupa pereduksian dan penyajian data selesai. Tahap akhir analisis ini diikuti dengan pengecekan kembali keabsahan data dan hasil analisis data.

\section{HASIL DAN PEMBAHASAN}

\section{Deskripsi Pra Siklus}

Kelas VIII G terdapat 29 peserta didik yang memiliki kemampuan yang lebih dibanding kelas lain. Namun demikian pada materi sistem pencernaan makanan mata pelajaran IPA diketahui bahwa pencapaian kompetensi peserta didik sangat beragam. Artinya ada yang memiliki nilai tinggi tetapi juga ada yang nilainya rendah. Dalam studi pendahuluan diketahui bahwa siswa kurang memiliki respon jika mengikuti pelajaran. Kurangnya respon siswa terhadap pembelajaran berakibat pada rendahnya kompetensi pengetahuan peserta didik dalam IPA. Kurangnya respon peserta didik lebih disebabkan karena guru belum menggunakan media pembelajaran yang tepat.

Selain itu, melalui tes kemampuan awal yakni materi sistem pencernan makanan IPA diketahui bahwa dari 29 siswa yang dapat dikatakan tuntas dalam pembelajaran atau memiliki nilai 70 hanya sebesar 59\% sedangkan 41\% lainnya masih dibawah KKM atau belum tuntas. Oleh karena itu upaya yang diasumsikan mampu mengatasi masalah tersebut adalah dengan penerapan media puzzle khususnya dalam materi sistem pencernakan makanan.

\section{Siklus I}

\section{Perencanaan Siklus I}

Berdasarkan struktur kurikulum SMP Negeri 2 Paron materi sitem pencernakan makanan terbagi menjadi 1) membuat model saluran pencernakan, 2) pencernakan mekanis dan kimiawi, dan 3) membuat model penyerapan di usus halus, dari ketiga materi ini diambil dua yaitu 
membuat model saluran pencernakan, membuat model penyerapan di usus halus dengan tujuan siswa mampu menerapkan IPA dalam kehidupan sehari-hari untuk menjaga kesehatan diri pada pola hidup sehat.

Untuk mencapai tujuan tersebut peneliti mempersiapkan media puzzle saluran pencernakan makanan secara kontekstual dari beberapa sistem pencernakan manusia dan sehari sebelum pelaksanaan pembelajaran siswa disuruh mencari gambar-gambar sistem pencernakan manusia dari rumah masingmasing serta mengamati gambar pokokpokok sistem pencernakan manusia yang diperolehnya. Kegiatan ini sebagai bekal awal atau refreshing peserta didik membaca materi sistem pencernakan dan fungsinya. Kegiatan ini juga dapat menjadi apersepsi terhadap kegiatan mapel IPA.

Media puzzle yang ditampilkan pada kegiatan pembelajaran ini adalah model gambar saluran pencernakan manusia yang dipotong-potong menjadi beberapa bagian diharapkan siswa mampu untuk memasangkan atau mengurutkan gambar sesuai dengan urutan saluran pencernakan yang telah diamati pada gambar sistem pencernaan makanan pada manusia dalam pertemuan awal pembelajaran.

\section{Pelaksanaan Siklus I}

Pelaksanaan pembelajaran siklus I dilaksanakan satu kali pertemuan dalam waktu 2 x 40 menit. Adapun skenario pembelajaran IPA materi sistem pencernakan manusia dilaksanakan dalam tiga tahap yaitu kegiatan pendahuluan, kegiatan inti, dan kegiatan penutup. Adapun kegiatan inti siklus I adalah: 1) Guru menanyangkan video orang sedang makan beserta model gambar saluran pencernakan makanan di layar monitor. 2) Guru menyuruh peserta didik untuk mengamati gambar. 3) Guru melakukan tanya jawab tentang sistem pencernakan yang pernah dibaca. 4) Guru menjelaskan pokok-pokok sistem pencernakan makanan. 5) Guru memberikan tugas masing-masing kelompok untuk menyusun potongan media puzzle sistem pencernaan manusia sesuai dengan gambar yang telah dimamati di awal pembelajaran. 6) Guru membimbing peserta didik berdiskusi secara berkelompok. 7) Peserta didik mempresentasikan hasil diskusi yang ditulis secara berkelompok

\section{Observasi Siklus I}

Observasi dilaksanakan selama kegiatan pembelajaran berlangsung oleh peneliti bersama dengan kolaborator. Kegiatan pengamatan dilaksanakan mulai dari tahap persiapan sampai dengan pelaksanaan pembelajaran. Pada siklus I ini siswa sangat antusias dan bergembira saat bercakap-cakap tentang kecepatan kerja kelompoknya, kekompakan yang dibangun. Pesrta didik sangat antusias dalam memasangkan puzzle sesuai dengan keperluan masing-masing siswa. Tentang presentasi secara umum siswa tampil dengan berani meskipun hampir semua siswa menyampaikan saat tampil awalnya merasa gemetar tetapi akhirnya agak hilang. Siswa merasa tenang dengan kegiatan pembelajaran seperti ini rasanya tidak ada waktu terbuang bahkan waktunya kurang panjang sehingga secara pribadi belum menghayati benar tetapi telah tercipta perasaan senang.

Berdasarkan hasil pengamatan pelaksanaan pembelajaran dan tes materi sistem pencernakan makanan setelah penerapan siklus I maka diperoleh hasil sebagaimana dalam tabel berikut.

Tabel 1. Pencapaian Kompetensi Siklus I

\begin{tabular}{lllll}
\hline Kompetensi & Tuntas & \% & $\begin{array}{c}\text { Tdk } \\
\text { Tuntas }\end{array}$ & \% \\
\hline Sikap & 22 & 76 & 7 & 24 \\
Pengetahuan & 20 & 69 & 9 & 31 \\
Ketrampilan & 27 & 93 & 2 & 7 \\
\hline
\end{tabular}

Dari tabel 1 tersebut dapat dijelaskan bahwa dari 29 siswa hasil pencapaian kompetensi sikap pada siklus I terdapat 22 atau $76 \%$ siswa yang telah tuntas dan 7 atau $24 \%$ siswa yang belum tuntas atau belum memiliki nilai $\geq 70$. Pencapaian kompetensi pengetahuan dari 29 siswa terdapat 20 
atau $69 \%$ tuntas dan 9 atau 31\% siswa tidak tuntas. Kompetensi keterampilan pada siklus I pencapainnya dari 29 siswa terdapat 27 atau 93\% siswa yang tuntas 2 atau $7 \%$ siswa yang tidak tuntas. Dengan hasil ini maka jika dikonfirmasi dengan target penelitian maka bisa dikatakan bahwa penerapan siklus I ini belum sesuai dengan target yang ditetapkan sehingga diperlukan tindakan lanjutan.

\section{Refleksi Siklus I}

Kegiatan refleksi terhadap proses dan produk dari hasil refleksi yang dilakukan secara kolaboratif dengan guru kelas VIII dilakukan bahwa tindakan proses pada setiap tahap sudah dilaksanakan dengan baik tetapi masih perlu beberapa perbaikan. Tahap pendahuluan sangat bagus dan menarik, kegiatan ini perlu dipertahankan karena penerapan awal media puzzle mampu membuat suasana pembelajaran menjadi menyenangkan, membuat siswa tidak tegang, tidak takut namun perlu diingat penerapan media ini jangan terlalu panjang agar tidak memakan waktu panjang. Isi puzzle tetap disesuaikan dengan materi pembelajaran yang akan dipelajari agar ada apersepsi pada pikiran siswa sehingga mempersiapkan diri secara fisik maupun mental.

Secara keseluruhan kegiatan inti pembelajaran sudah bagus bahkan sangat bagus dan sangat padat tetapi kegiatan ini ada kekurangan karena waktunya terbatas hanya dua jam pembelajaran hendaknya kegiatan ada yang dikurangi karena siswa belum menghayati dengan benar terhadap puzzle dan sudah dikejar dengan tugas-tugas yang harus diselesaikan. Ini membutuhkan total phisikal respon yaitu mengikuti dan merespon pembelajaran dengan physic secara total sesuai jika kondisi kelas seluruhnya memiliki kemampuan yang baik tetapi kelas VIII G memiliki kondisi siswa dengan kemampuan beragam maka siswa perlu diberi kesempatan untuk menghayati hasil pembelajaran sehingga sempat berfikir dengan baik.

Berdasarkan hasil observasi dan refleksi diatas dapat disimpulkan bahwa proses dan hasil pelaksanaan pembelajaran pada siklus I masih terdapat kekurangan. Dari data nilai menunjukkan siswa belum tuntas secara klasikal meskipun ada siswa yang telah berhasil mendapat nilai tinggi. Oleh sebab itu peneliti bersama kolaborator berdiskusi untuk merancang kembali kegiatan pembelajaran siklus II untuk memperbaiki kekurangan pada siklus I serta meningkatkan keberhasilan prestasi siswa dalam Mata pelajaran IPA materi sisitem pencernaan makanan pada manusia.

\section{Siklus II}

\section{Perencanaan Siklus II}

Perencanaan tindakan mata pelajaran IPA materi sistem pencernaan makanan dengan media puzzle dalam kegiatan siklus II ini dirancang secara kolaborator dengan guru IPA kelas VIII di SMP Negeri 2 Paron. Perencanaan ini juga disusun berdasarkan hasil refleksi siklus I dengan materi sistem pencernaan makanan .

Kegiatan ini dimulai dengan menyusun silabus yang mengalami revisi pada kegiatan pembelajaran agar lebih menonjolkan penggunaan media puzzle. Pada siklus I terlalu banyak kegiatan kelompok sehingga, tidak mencerminkan kegiatan individu sehingga perlu ada kegiatan individu dan dinilai secara perseorangan. Pada silabus juga mengalami perubahan indikator pembelajaran berupa siswa mampu menentukan susunan puzzle sistem pencernaan makanan beserta fungsinya dan enzim yang membantu pencernaan, dan siswa mampu mempresentasikan hasil kerjanya.

\section{Pelaksanaan Siklus II}

Pelaksanaan pembelajaran siklus II dilaksanakan satu kali pertemuan dalam waktu 2 x 40 menit. Adapun skenario pembelajaran mata pelajaran IPA materi sistem pencernaan makanan dilaksanakan dalam tiga tahap yaitu kegiatan pendahuluan, kegiatan inti, dan kegiatan penutup. Adapun kegiatan inti siklus II adalah: 1) Peserta didik mengamati gambar 
fungsi organ pencernaan yang di sediakan oleh guru. 2) Peserta didik bertanya jawab tentang materi fungsi organ pencernaan makanan dan fungsinya di pandu oleh guru. 3) Peserta didik mencatat halhal yang penting dari mengamati puzzle fungsi organ pencernakan makanan. 4) Peserta didik menyusun gambar puzzle yang telah disediakan guru sesuai dengan petunjuk. 5) Peserta didik mendiskusikan fungsinya organ pencernaan makanan dari hasil susunan gambar puzzle. 6) Peserta didik mempresentasikan hasi kerja kelompok. 7) Peserta didik menempelkan hasil pekerjaannya pada dinding yang telah ditentukan guru. 8) Peserta didik menyimpulkan hasil belajar dengan teman satu kelas di pandu oleh guru. 9) Peserta didik menilai pekerjaan kelompok berdasarkan rubrik penilaian yang diberikan guru

\section{Observasi Siklus II}

Tahap perencanaan guru bersama kolabor berdiskusi memperbaiki silabus yang disusun dengan mengalami perubahan pada kegiatan pembelajaran menyesuaikan dengan media puzzle yang akan dilaksanakan yaitu pada pembentukan kelompok dibuat secara acak. Media puzzle fungsi organ pencernaan makanan, siswa harus belajar dari model gambar yang sama sehingga perhatian siswa terfokus pada puzzle. Guru membuat puzzle yang menarik perhatian siswa dengan mengkongkritkan fungsi organ pencernaan makanan dengan tujuan yang jelas. Penilaian tetap dilaksanakan melalui penilaian proses masing-masing pengamat bertugas mengamati aktivitas siswa dari kegiatan, keberanian, bertanya usul, saran, berpendapat maupun sikap siswa dalam menanggapi pembelajaran secara antusias, aktif atau sebaliknya. Disamping penilaian proses, dilaksanakan juga penilaian berbasis kelas dari siswa melalui menyunting pekerjaan siswa dan menilai berdasar rubrik yang disediakan. Kemudian dilaksanakan penilaian produk berupa sistem pencernaan makanan yang telah dibuat serta tes untuk mengetahui kompetensi materi sisitem pencernaan makanan.

Berdasarkan hasil pengamatan pelaksanaan pembelajaran dan tes materi sistem pencernakan makanan setelah penerapan siklus II maka diperoleh hasil sebagaimana dalam tabel berikut.

Tabel 2 Pencapaian Kompetensi Siklus II

\begin{tabular}{lcccc}
\hline Kompetensi & Tuntas & $\%$ & $\begin{array}{c}\text { Tidak } \\
\text { Tuntas }\end{array}$ & $\%$ \\
\hline Sikap & 24 & 83 & 5 & 17 \\
Pengetahuan & 25 & 86 & 4 & 14 \\
Ketrampilan & 29 & 100 & 0 & 0 \\
\hline
\end{tabular}

Tabel 2 menunjukkan bahwa dari 29 siswa hasil pencapaian kompetensi sikap pada siklus I terdapat 24 atau $83 \%$ siswa yang telah tuntas dan 5 atau $17 \%$ siswa yang belum tuntas atau belum memiliki nilai $\geq 70$. Pencapaian kompetensi pengetahuan dari 29 siswa terdapat 25 atau $86 \%$ tuntas dan 4 atau 14\% siswa tidak tuntas. Kompetensi keterampilan pada siklus I pencapainnya dari 29 siswa terdapat 29 atau $100 \%$ siswa yang tuntas 0 atau $0 \%$ siswa yang tidak tuntas. Dengan hasil ini maka jika dikonfirmasi dengan target penelitian maka bisa dikatakan bahwa penerapan siklus II ini telah sesuai dengan target yang ditetapkan sehingga tidak diperlukan tindakan lanjutan.

\section{Refleksi Siklus II}

Pada kegiatan inti pembelajaran siklus II pertanyaan guru yang provokatif memberi inspirasi siswa untuk mencari jawaban yang terdapat dalam puzzle sehingga siswa dapat menentukan jawabannya. Siswa mampu menemukan dengan jawaban dan alasan beragam tetapi dapat disatukan menjadi kesepakatan penilaian. Pada kegiatan penyususnan puzzle si siklus II ini siswa lebih giat dan aktif karena tidak hanya menyusun tetapi siswa harus mencari jawaban yang tepat untuk fungsi masing-masing alat pencernakan tersebut. Pada kegiatan melaporkan hasil diskusi masih ada kekurangan setelah ditemukan sistematika sistem pencernakan 
makanan dan penilaiannya, laporan 2 kelompok kurang mendapat tanggapan dari kelompok lain, hanya ditanggapi oleh satu anggota. Disini peran guru harus tetap memotivasi agar siswa merespon terhadap kelompok lain. Alasan penyaji memang tidak memberikan kesempatan kepada peserta diskusi karena tujuan telah tercapai (menguasai kompetensi sistem pencernaan makanan) dan waktu pembelajaran terbatas padahal masih ada kegiatan berikutnya.

Kekurangan lain yaitu hasil diskusi kelompok sudah dibahas tetapi belum diberikan penilaian secara terbukameskipun telah dicatat oleh pengamat. Pelaksanaan presentasi sudah bagus dilaksanakan seluruh kelompok bertanggung jawab.

Kegiatan pembelajaran materi sistem pencernaan makanan sudah dilaksanakan berjalan sesuai dengan tujuan. Dari hasil evaluasi siklus II diketahui bahwa dari 29 siswa terdapat 25 atau $86 \%$ siswa yang telah tuntas dan 4 atau 14\% siswa yang belum tuntas atau belum memiliki nilai $\geq$ 70. Adapun rata-rata prestasi belajar siklus II sebesar 75 Dengan hasil ini maka jika dikonfirmasi dengan target penelitian maka bisa dikatakan bahwa penerapan siklus II ini telah sesuai dengan target yang ditetapkan sehingga tidak diperlukan siklus lanjutan.

Pembelajaran yang menarik tidak lepas dari pendekatan, strategi, teknik, dan metode yang digunakan oleh guru. Hal tersebut juga harus disesuaikan dengan materi dan karakteristik, siswa maupun kondisi kelas dengan sarana prasarana yang dimiliki sekolah. Susilana (2007) menyampaikan bahwa media dan metode itu bersifat prosedural, dalam arti bahwa penerapan suatu metode dalam pembelajaran harus dilakukan dalam langkah-langkah yang teratur, secara bertahap yaitu mulai dari perencanaan pembelajaran, penyajian, penilaian proses dan hasil pembelajaran. Keberhasilan pembelajaran selain langkah-langkah tersebut diatas ada faktor lain yang tak kalh pentingnya dalam mendukung keberhasilan pembelajaran yaitu media pembelajaran. Arsyad (2009) menyatakan disamping penggunaan alat-alat yang tersedia, guru juga dituntut untuk dapat mengembangkan keterampilan membuat media pembelajaran yang akan digunakannya dalam proses pembelajaran.

Kolaborasi penggunaan media pembelajaran ternyata mampu berperan membentuk sikap siswa untuk serius mengikuti pembelajaran yang berarti menyimak kritis karena pengamatan dilakukan untuk menjawab pertanyaan (Susilana, 2007). Media pembelajaran ini juga mengaktifkan seluruh siswa untuk melaksanakan aktifitas belajar melalui berpendapat menyampaikan usul, saran, mempertahankan hasil diskusi melaporkan hasil diskusi, menaggapi, menanyakan, menjawab, memimpin diskusi dan sebagainya. Media ini juga menumbuhkan sikap bertanggung jawab melaksanakan tugas dari guru untuk menunjukkan penguasaan kompetensi berupa menghafal urutan organ pencernakan dan fungsinya sebagai tujuan utama yang dicapai dalam pembelajaran. Media pembelajaran ini juga mampu meningkatkan keaktifan siswa untuk belajar. Secara umum tujuan penelitian sebagaimana dalam rumusan masalah dapat tercapai yakni peningkatan ketercapaian kompetensi materi sistem pencernaan makanan melalui melalui media puzzle.

Penerapan media puzzle dalam pembelajaran IPA materi sistem pencernaan makanan dapat meningkatkan ketuntasan belajar. Indikator peningkatan tersebut yakni 1) angka ketuntasan mengalami peningkatan yakni siklus I sebesar 69\% kemudian pada siklus II meningkat menjadi $84 \%, 2$ ) angka ketidaktuntasan mengalami penurunan yakni jika pada siklus I sebesar 31\% kemudian pada siklus II menurun menjadi $14 \%$ 3) rata-rata secara klasikal mengalami kenaikan dari 71 pada siklus I meningkat menjadi 74 pada siklus II sehingga dengan hasil ini bisa dikatakan bahwa dengan media puzzle kompetensi pengetahuan IPA dapat ditingkatkan.

Sedangkan kompetensi keterampilan siswa dari siklus I dan siklus II tampaknya juga meningkat seiring dengan meningkatnya kompetensi sikap, kompetensi pengetahuan siswa. Penerapan media puzzle dalam pencapaian 
kompetensi keterampilan siswa dalam mata pelajaran IPA materi sistem pencernaan makanan dapat ditingkatkan. Indikator peningkatan tersebut yakni 1) angka ketuntasan mengalami peningkatan yakni siklus I sebesar 93\% kemudian pada siklus II meningkat menjadi 100\%, 2) angka ketidaktuntasan mengalami penurunan yakni jika pada siklus I sebesar $7 \%$ kemudian pada siklus II menurun menjadi $0 \% 3$ ) rata-rata secara klasikal mengalami kenaikan dari 79 pada siklus I meningkat menjadi 84 pada siklus II sehingga dengan hasil ini bisa dikatakan bahwa dengan media puzzle kompetensi keterampilan siswa pada mata pelajaran IPA materi sistem pencernaan makanan dapat ditingkatkan.

\section{SIMPULAN}

Pembelajaran saintifik dengan media puzzle pada mata pelajaran IPA materi sistem pencernaan makanan di kelas VIII G SMP Negeri 2 Paron tahun pelajaran 2014/2015 dapat ditingkatkan pada seluruh kompetensi yaitu kompetensi sikap, kompetensi pengetahuan dan kompetensi keterampilan.

\section{DAFTAR PUSTAKA}

Azhar, Arsyad. 2009. Media Pembelajaran. Rajagrafindo Persada, Jakarta, Depdiknas

Depdiknas. 2005. Materi Pelatihan Terintegrasi IPA 3: Pelatihan tindakan kelas, Jakarta. Direktorat pendidikan Lanjutan Pertama, Dirjen Dikdasmen

Kemendiknas. 2013. Materi Pelatihan Implementasi Kurikulum 2013 mapel IPA SMP. Jakarta.BPSDMPK PMP Kemdiknas.

Kemendiknas. 2013. Materi Pelatihan Guru Pendamping Imlementasi Kurikulum 2013 SMP-IPA, Jakarta.

Susilana, Rudi. 2007. Media pembelajaran. Bandung. $C V$. Wacana Prima 